\title{
Politika i pozorište kao čuvari zajedničkog sveta
}

\author{
BOJAN KOVAČEVIĆ \\ Fakultet političkih nauka, Univerzitet u Beogradu
}

\begin{abstract}
Sažetak
Autor zastupa tezu da u istoriji evropske drame i pozorišta leži originalan odgovor na pitanje odnosa između poretka i promene koje je u središtu preokupacija klasičnih političkih mislilaca. Pozorište ima temeljni zadatak očuvanja zajedničkog sveta bez koga i samo ostaje lišeno smisla postojanja. Gurnuvši nas isprva u provaliju zapitanosti nad smislom, veliki dramski pisci nas potom iz nje izvlače odgovorom koji je njihovoj mašti šapnulo doba u kojem su živeli. Oni među njima koji su postojeći poredak čuvali, poput Eshila, Molijera i Rasina, gledaocima su obznanjivali njegovu utemeljujuću ideju. Oni, poput Getea i Šlera, čiji je umetnički genij u istoriji prepoznao svrhoviti razvoj ka republici slobodnih građana, pozorište su koristili kao mesto estetskog poučavanja društvene elite od koje se očekuje da dolazak novog zajedničkog sveta ubrza. Za stvaraoce u revolucionarnim vremenima, poput Brehta i Pirandela, pozorišne daske služile su kao nadahnuće za radikalnu promenu svih postojećih društvenih i političkih ustanova. Konačno, autorima poput Euripida, Ibzena, Čehova i Strindberga pozorište je omogućilo da zavape za starim svetom koji je ostao bez svoje ideje o poretku i zato nestaje.
\end{abstract}

Ključne riječi: političko, pozorište, drama, zajednički svet, poredak

\section{Uvod: Platon, pozorište i smrt polisa}

U vremenu igre grčke mladosti po lepoj površini sveta, jedan usamljeni aristokratski duh, nadmoćan i arogantan predstavnik te nestrpljive i radoznale mladosti zaokupljene vedrim nadmetanjem u pesništvu, politici i umetnosti, shvata da u prirodi, ljudima i njihovim mislima nema ničeg trajnog i postojanog. ${ }^{1}$ Heraklitova

1 Članak je zamišljen kao uvod u zajedničke studije dramaturgije i politike. Radi se, dakle, o početnom koraku, pokušaju da se pronađe teorijsko opravdanje spajanja ove dve naučne discipline. Utoliko je bilo neophodno dobiti mišljenje što više naučnika čija se istraživačka radoznalost kreće po sferama politikologije, dramskih umetnosti, teorije i istorije književnosti. Želeo 
filozofija nosi obeležje melanholičnog dečaštva iznenada nateranog da počne da misli o sebi. Zavirivši mislima ispod onog vidljivog, opipljivog, on na trenutak oseti da je temperatura sveta koji ga okružuje za stepen hladnija i onda poviče u znak pobune i protesta: sve teče, sve je prolazno, ništa ne ostaje (Pater, 2002: 6). Ovaj pre vremena sazreli dečak živi usamljen među usnulom svetinom, nesvesnim glumcima predstave koja se brzo odvija i približava svom kraju. "Jedno te isto su u nama: živo i mrtvo, budno i spavajuće, mlado i staro. Jer ovo drugo, promenivši se, postaje ono prvo, i obratno, ono prvo, promenivši se - ovo drugo" (Heraklit, 1981: 41). Promena je nužna, ništa je ne može zaustaviti, ona je večni zakon prirode koji se skrio ispod površine bezbrižnog sveta, život - smrt, noć - dan, biće - nebiće, java - san. "Što budni gledamo - jeste smrt, što u snu - jeste život" (ibid.). Jedini budan među dečacima utonulim u san, Heraklit usamljeno vidi kraj sveta helenske vedrine uverenog u svoju večnost, sveta lepršave borbe i nade da ljudi delom i rečju mogu zaslužiti mesto u kosmosu u kome je sve besmrtno osim njih samih. Kada se grčka mladost konačno probudi iz lepog sna, povikao je na svoj zagonetni način mračni filozof iz Efesa, videće smrt svojih shvatanja, običaja, načina života, polisa, demokratije i pozorišta.

Herojski napor da raskošnom imaginacijom zaustavi odrastanje, starenje i smrt grčkog sveta učiniće Platon. Ovaj mladi plemić koga je priroda obdarila raznovrsnim talentima mogao je postati najveći sofista, tragičar, političar, junak svog nestrpljivog doba lake veselosti, govorništva, inovatorstva, individualizma, učestalih ustavnih i političkih eksperimenata. Platon je, međutim, bio ljubavnik, strasno zaljubljen u svet koji ga okružuje (Pater, 2002: 91). U prevlasti nepostojane, radoznale jonske duše u stalnom pokretu nad dorskom, koja disciplinuje i čuva, on prepoznaje najvećeg neprijatelja svog voljenog sveta - promenu. Obustavljanje promene postaje cilj njegove filozofije (Popper, 2003). Ulazi u rat sa sofistima koji je ubrzavaju podstičući ljude na neodgovornost, spontano kretanje ka novom i nepoznatom, na diskreditovanje sopstvene prošlosti. Pokreće parnicu protiv politike (Volin, 2007: 53-94). Iskustvo burnog atinskog političkog života uči ga da politika znači neizvesnost, nepredvidljivost, sukobe, borbu za vlast, revolucije, učestale promene oblika vladavine. "U ovoj borbi za vlast, satkanoj od rivalskih ambicija i sukobljenih interesa, leži uznemiravajući faktor 'politike', izvor nestabilnosti i promene, i ne-

bih da izrazim veliku zahvalnost uglednim kolegama iz različitih oblasti društveno-humanističkih nauka koji su pročitali tekst. Svojim podstrekom, sugestijama i oštrim kritikama oni su me naveli da poverujem da sam na dobrom putu. Primedbe koje su neki od njih uputili pomogle su mi da značajno unapredim kvalitet samog teksta. Sa Fakulteta političkih znanosti u Zagrebu to su Dragutin Lalović i Tihomir Cipek, sa Fakulteta dramskih umetnosti u Beogradu Ivan Medenica, sa Filološkog fakulteta u Beogradu Milo Lompar, Vladeta Janković i Kornelije Kvas, a sa Fakulteta političkih nauka u Beogradu Slobodan Samardžić, Marko Simendić, Aleksandar Milošević i Nikola Bjeljinac. 
izbežno stvara stanje u kome se politički oblici i odnosi razvijaju sa minimumom smišljenog usmeravanja a maksimumom spontanosti" (ibid.: 55). Mnjenja, prividi ne mogu obezbediti red, harmoniju i trajni poredak, mislio je Platon. Zato on svoju idealnu državu pravi prema uzoru koji u dosluhu sa božanskim pronalazi izvan političke zajednice, u svetu ideja. U državi, koju ovaj filozofski slikar inspirisan dorskom ljubavlju prema poretku slika na praznom platnu, nema mesta za iskričavi, šarenoliki, veselo spontani život u stalnom pokretu, ali ni za one koji ga podražavaju, pesnike.

Podražavati mnoge stvari preteško je za jednog čoveka pošto je svako stvoren tako da može dobro obavljati samo jedan posao, progovara Platonov Sokrat u trećoj knjizi Države (Platon, 2005). Zato ne treba očekivati da bi jedan isti čovek mogao postići velik uspeh u postavljanju tragedija. Ako bi, ipak, u državu došao čovek koji bi bio tako okretan da bi mogao podražavati sve raznolike stvari koje se u tragedijama pojavljuju, "onda bismo mu mi ukazali božansku počast, kao da je svetac koji zaslužuje divljenje, a ipak bismo mu rekli da kod nas u državi ne postoji takav čovek i da ne sme postojati i poslali bismo ga u drugu državu" (ibid.: 68). Slikar i pesnik prikazuju stvari onakve kakve izgledaju, a ne onakve kakve stvarno jesu. Predmet poezije su prividi. Onaj ko građanima okupljenim u Dionisovom pozorištu slika život atinskog polisa, ne zna šta je ispravno i dobro, već podražava ono što se "svetini i onima koji ne znaju ništa pričinjava kao lepo (dobro)" (ibid.: 247). Pozorište, tragedija, lakomislena demokratska publika ubrzavaju iščezavanje Platonovog sveta. Otuda njegov prezir prema pesnicima koji svojim delima oblikuju karaktere ljudi, a nisu filozofi i ne poznaju istinu stvari, već pokušavaju da uhvate šta drugi o njoj misle. "O dragi Homere", ironično se pita njegov Sokrat, "ako si naučio koje su to težnje koje ljude u javnom i privatnom životu čine boljima ili gorima, onda nam reci koja je država tvojom zaslugom dobila uređenje bolje od onoga koje je Likurg dao Lakedemonu, i kakvo su i mnoge druge države, velike i male dobile od svojih zakonodavaca?" (ibid.: 244).

Ni Platonov najveći učenik Aristotel ne prihvata Heraklitovu filozofiju proste promene "lišene odredbe identiteta sa sobom, trajnosti, opštosti. Reka se stalno menja - ali ona takođe traje više godina - i uz to predstavlja jedan lik" (Hegel, 1975: 261). Međutim, za razliku od svog učitelja on promenu ne pokušava da zauzda. Naprotiv, nepostojanost, kretanje, odlučujući su za Aristotelovu filozofiju u kojoj se svrha u prirodi i ljudima ostvaruje tek kroz delanje, shvaćeno kao promena koja ostaje identična sa samom sobom i predstavlja samoodređivanje (ibid.). Zbog toga on i ne osuđuje pesnike, pisce tragedija koji podražavaju vidljivi svet, svet materije shvaćen kao svet mogućnosti, i priču pričaju prikazujući "radnju i život, sreću i nesreću, a sreća i nesreća leže u radnji, i ono što čini cilj našeg života to je neko delanje, a ne kakvoća" (Aristotel, 2008: 67). Čovekovu prirodu treba razumeti u 
smislu potencijalnosti da učini velika dela u svetu obeleženom napetostima, kretanjem, težnjama, nadama, strahovima, ambicijama, uverava nas Aristotel. On tako oslobađa Platonovog filozofa kralja preteškog bremena usamljeničke borbe protiv besmislene prolaznosti života i prepušta je građanima polisa. Veličina smrtnika nalazi se u unutrašnjoj mogućnosti da stvore nešto trajnije od života, besmrtne reči i dela. Tom zadatku najčešće su dorasli baš oni ljudi koje Platon smatra nedostojnim podražavanja, one "šarenolike naravi koje svetinu najviše uzbuđuju" (Platon, 2005: 251). Takvi su junaci tragedija čije sudbine rasvetljavaju dublju istinu o ljudima i njihovim zajednicama. Za razliku od istoriografa usredsređenih na pojedinačno, pesnici svojim talentom uspevaju da prikažu ono opšte u delima neobičnih, izuzetnih ličnosti (Aristotel, 2008: 73). Tako se njihova priča čuva od zaborava. "“Cjelina' radnje, teorijska fikcija, utemeljuje logos totaliteta u kojemu se ljepota bitno misli kao protok vremena koji je postao ovladivim. Drama znači ovladanu rijeku vremena koja se učinila preglednom" (Lehman, 2004: 50).

Platon iz svoje idealne države proteruje pozorište u kome demokratska svetina uplašeno, ili sa sažaljenjem, posmatra podražavanje burnog života polisa. Svrstati ga, međutim, među neprijatelje pozorišta bilo bi pogrešno. Platon je, u stvari, njegov radikalni reformator, pisac novog tipa filozofske drame u kojoj Sokrat igra glavnu ulogu (Puchner, 2010). On se sa pesnicima takmiči, stvara drugačije pozorište u kojem se begunac iz pećine vraća u svet privida, među ljude, kako bi im preneo iskustva stečena u neprolaznom svetu ideja. Njegova Država zaista se čita kao najlepše dramsko delo, Šekspirov Hamlet ili Danteova Božanska komedija, u kojem moćni intelekt preoblikuje neponovljive društvene, istorijske, političke, kulturne prilike svog doba, istovremeno im se suprotstavljajući i stapajući se sa njima (Pater, 2002: 4). U svojoj drami Platon teoriju ideja prikazuje na pozorišni način sa konkretnim likovima koji su se sa svojim željama, strahovima, nadanjima obreli u konkretnim životnim prilikama. To je možda najvidljivije u Fedonu u kojem uporedo sa neizvesnom filozofskom potragom za dokazom o besmrtnosti duše Platon umetnički prikazuje promene osećanja Sokratovih sagovornika i slušalaca, zebnju, nevericu, plač i na kraju olakšanje (Platon, 1982). Zaljubljen u svet koji želi da sačuva od prolaznosti, Platon idejama daje ljudski lik. Ideju pravičnosti otelotvoruje njegov učitelj Sokrat. U svojoj filozofskoj drami Platon na scenu prvo izvodi stvarne ljude da bi ih potom pretvorio u forme, pokazujući time da su ideje te koje oblikuju ono vidljivo (Puchner, 2010: 19). Scena na koju on izvodi glumce predstavlja laboratoriju, umetničko-filozofskim darom kontrolisanu verziju sveta iz kog su likovi uzeti. Oni su i dalje materija, ali materija u službi filozofskog projekta potrage za istinom. Potraga se odvija u formi dijaloške drame kao savršenog posrednika između empirijske stvarnosti i sveta ideja. Na scenu se prvo izvodi prolaznost, prividi, različita mnjenja. Sve što postoji dovodi se u pitanje. Sledi borba protiv relativnosti i sofista. 
Kada napokon razgrne naslage pogrešnih uverenja, shvatanja, navika i običaja svog zahuktalog vremena, Platon rečima, kroz usta svog glavnog lika, Sokrata, obznanjuje ono što jeste.

Nije Platon bio jedini čuvar apolonovskog načela harmonije i reda među grčkim umetnicima. Zajednički svet pokušavali su da sačuvaju i veliki pozorišni učitelji vrline Eshil i Sofokle (Đurić, 1972: 268-304). Dok je Platon herojski pokušao da prolaznost pobedi podražavanjem sveta ideja, slavni pobednici nadmetanja tragičara na Dionisovim svečanostima činili su to obznanjivanjem temeljnih vrednosti demokratskog polisa u kojem su živeli. Tako Eshil prikiva svog Prometeja za stenu, stajući na stranu Diva, države, reda i harmonije naspram pojedinca čiju tragičnu sudbinu određuje neobuzdana želja za napretkom i pravdom (Eshil, 1994a). U Orestiji on opravdava Agamemnonovo žrtvovanje sopstvene ćerke zarad ratnog uspeha države, učeći građane da je pripadnost polisu važnija od svake druge, pa čak i od krvne pripadnosti porodici. Odluku o sudbini Oresta, koji iz osvete ubija majku, Eshil izvlači iz pretpolitičkog rodovskog lanca krvne osvete i prenosi na Aeropag kao političku ustanovu demokratskog polisa. Odlučujući glas kojim se Orest oslobađa krivice pripada boginji Atini, ćerki boga Zevsa kao jedinog garanta pravde i smisla na zemlji. Time Aeropag, kao manifestacija božanske pravde na zemlji, dobija pokriće da u svim narednim slučajevima krvnog delikta donosi konačnu presudu (Eshil, 1994). ${ }^{2}$ Kao kaznu prema svojoj prirodi, koja ga je navela da ubije oca i oženi majku, Sofoklov kralj Edip sebe oslepljuje. On time postupa kao odgovoran vladar, koji nemilosrdno kažnjava svoj telesni identitet, krivca za političku krizu i nesreću koja se spustila na polis (Sofokle, 1994). ${ }^{3}$

Mračni Heraklit je, ipak, bio u pravu. Umiranje zajedničkog sveta ništa nije moglo da zaustavi. U tome nije uspeo ni Platon sa svojom filozofskom parnicom protiv politike, pozorišta i demokratije, ni veliki tragičari nadahnuti idealima demokratskog polisa, ni posvađana grčka mladost izgubljena u Peloponeskom ratu i neuspešnim ustavnim i političkim eksperimentima. Sanjali su Grci čak i kada su Euripidove Bakhe gledali (Euripid, 1994). Mislili su da je raskomadanog Penteja stigla zaslužena kazna zato što je bogove uvredio dok im je pesnik pričao priču o smrti njihovog polisa, demokratije i tragedije (Fischer-Lichte, 2002: 28-33). Pentej nije stradao zato što je bio na pogrešnoj strani, divlje strasti, nepravde i terora, već zato što je udružena snaga neobuzdanog nasilja odbeglih i sa prirodom sjedinjenih bakhi bila veća od njegove. Grčka je potonula u varvarstvo, glumci su trajno sišli sa pozornice Homerovog sveta u kojem se moglo "uvek odličan biti i druge sve nadmašavati” (Homer, 2002: 162), tužno je obznanio Euripid.

\footnotetext{
2 Zahvaljujem Ivanu Medenici što je podelio sa mnom ovaj uvid.

3 Zahvaljujem Ivanu Medenici na ovoj sugestiji.
} 
Platon i grčki pesnici nisu ostavili uputstvo za očuvanje zajedničkog sveta, već samo jasno postavljeno pitanje za mislioce politike i dramske pisce potonjih vekova: kako pomiriti red i politiku, postojanu formu i iskričavi život, apolonovski i dionizijski princip? Kako sačuvati zajednički svet u kojem život pojedinca može zadobiti viši smisao? Može li se ljudima prepustiti da odgovor traže sami, zdravim razumom u svojoj državi ili, pak, odgovor leži izvan političke zajednice, u svetu ideja, i može ga obznaniti onaj koji ljudima vlada?

Istorija nas uči da su teoretičari tek u vremenima kada postojeće političke ustanove i društvene norme više nisu bile u stanju da integrišu društvo, u situaciji egzistencijalne krize, uspevali da otkriju nova značenja starog Platonovog problema očuvanja političke zajednice. Uvid da pitanje opstanka zajedničkog sveta stoji u neposrednoj vezi sa pitanjem odnosa između vanrednog i normalnog iznedrilo je dvoje velikih mislilaca politike XX veka koji su intelektualno sazrevali u burnim okolnostima Vajmarske Republike, Hanu Arent (Hannah Arendt) i Karla Šmita (Carl Schmitt). Oboje zaključuju da u normalnom stanju, periodu materijalnog blagostanja, građanske sigurnosti i neupitanosti za smisao života, vreba najveća opasnost za zajednički svet. Za Šmita ta opasnost leži u zaboravu ideje o poretku (Šmit, 2001), a za Hanu Arent u svođenju politike na administraciju, žrtvovanju javne slobode zarad stabilnosti poretka, povlačenju građana u privatnu sferu i ukidanju prostora za otpočinjanje novog (Arendt, 1990; 1998). Tek u vanrednom, kada se država nađe pred ambisom, otvara se nova prilika za političko. Za Šmita to je prilika za diktatora koji tumači smisao i obznanjuje u moderni uvek odsutnu ideju o poretku, a za Arent ona pripada građanima koji spontanim udruživanjem, dogovaranjem kroz sporazume i obećanja iznova utvrđuju temelje svog zajedništva.

Uključivanje Šmita i Arent u raspravu o problemu mirenja političkog i poretka može na prvi pogled izgledati neopravdano. Naime, intelektualna potraga za odgovorom na pitanje očuvanja zajedničkog sveta odvela je oba velika autora u slepu ulicu oštrog suprotstavljanja stanja normalnog, u kojem političko postepeno iščezava (Arent) ili biva neutralisano (Šmit), i vanrednog, kao nove prilike za političko delovanje građana (Arent) ili odluku diktatora (Šmit). Uprkos tome, tvrdimo da upravo radovi Šmita i Arent mogu imati odlučujući podsticaj za promišljanje problema političkog u pozorištu, i to iz dva razloga. Prvi je taj što veliki pravnik i filozofkinja ubedljivo razotkrivaju opasnost iščezavanja zajedničkog sveta u vremenu materijalnog blagostanja i građanske sigurnosti. Terajući nas da pogledamo ispod površine bezbrižnog sveta oblikovanog ustanovama liberalne demokratije, Šmit i Arent u nama bude nespokoj, uznemirenost, zapitanost. Oni nas tako podstiču da postavimo zaboravljeno pitanje temelja političkog zajedništva. Da je upravo to uloga koju na sebe preuzima i pozorište pokazaćemo u ovom članku. Drugo, intelektualni neuspeh ovih dvoje velikih mislilaca da razreše zagonetku odnosa političkog 
i poretka, vanrednog i normalnog, praćen istorijskim krahom zajednice u kojoj su sazrevali, Vajmarske Nemačke, usmerava našu potragu ka drugim sferama, među kojima je i autonomni svet umetničke istine o pitanju zajedničkog života ljudi. Kako dovesti u sklad formu, kao ono trajno što postavlja granicu i koči, sa političkim, kao onim životnim što se zauzdavanju opire, ostaje u stalnom vrenju i potrazi za novim? ${ }^{4}$

Osnovna teza ovog rada jeste da u istoriji evropske drame i pozorišta leži originalan odgovor na pitanje odnosa između poretka i promene koje je u središtu preokupacija klasičnih političkih mislilaca. Kada se problem postavi na ovakav način, postaje jasno da rad neće biti sveden na razmatranje angažovanog, političkog pozorišta, koje neposredno reaguje na politička zbivanja, a gledaoce naoružava znanjima neophodnim za promenu društva. Umesto toga, pozorište se posmatra kao mesto potrage za umetničkom istinom o temeljima političkog zajedništva ljudi. Pozorište, naime, ima temeljni zadatak očuvanja zajedničkog sveta bez koga i samo ostaje lišeno smisla postojanja. Drama ideja koja se u državama odigrava samo u retkim istorijskim prilikama velikih kriza u pozorištu se odvija čak i u najmirnijim društvenim okolnostima. Pozorište nas prvo dovodi u stanje u kojem se našao pre vremena odrasli Heraklit, izvlači nas iz normalnog, rutinskog, svakodnevnog u kojem se preteško pitanje o smislu, suštini života pojedinca i zajednice sakrilo iza postojećih društvenih normi, brige za ono što je prolazno, posao, uspeh ili fizički izgled. Praveći u dušama gledalaca nered bezobalne zapitanosti nad svim postojećim sličan onome u kome se našla Platonova Atina, veliki pozorišni stvaraoci publiku isprva dovode u granično stanje, stanje vanrednog, egzistencijalne krize. Budeći gledaoce uljuljkane u površinu empirijskog sveta, pozorište ih tera da postave temeljna pitanja politike: Šta u životu ima značaja i vrednosti? Koja je svrha države? Gurnuvši nas isprva u provaliju zapitanosti nad smislom, veliki dramski pisci nas potom iz nje izvlače odgovorom koji je njihovoj mašti šapnulo doba u kojem su živeli. Oni među njima koji su postojeći poredak čuvali, poput Eshila, Molijera i Rasina, gledaocima su obznanjivali njegovu utemeljujuću ideju. Oni, poput Getea i Šilera, čiji je umetnički genij u istoriji prepoznao svrhoviti razvoj ka republici slobodnih građana, pozorište su koristili kao mesto estetskog poučavanja društvene elite od koje se očekuje da dolazak novog zajedničkog sveta ubrza. Za stvaraoce u revolucionarnim vremenima, poput Brehta i Pirandela, pozorišne daske služile su kao nadahnuće za radikalnu promenu svih postojećih društvenih i političkih ustanova. Konačno, autorima poput Euripida, Ibzena, Čehova i Strindberga pozorište je omogućilo da tužno zavape za starim svetom koji je ostao bez svoje ideje o poretku i zato nestaje.

${ }^{4}$ Zahvaljujem Dragutinu Laloviću što mi je ukazao na intelektualne ćorsokake u razumevanju političkog kod Šmita i Arent. 
Iščezavanje zajedničkog sveta bez koga nema ni politike ni dramskog pozorišta temeljna je odlika vremena u kojem živimo (Lehman, 2004). Ono novo što donosi naše doba jeste da brisanje javnog prostora na kome je moguće biti viđen i videti, gde se rađa nešto novo ili spašava od smrti ono staro, ide uporedo sa ukidanjem razlike između vanrednog i normalnog stanja (Agamben, 2013). Kako sačuvati zajedničku kuću u toj kritičnoj situaciji osnovni je problem sa kojim se suočavaju budući politički delatnici i dramski pisci. Bez zajedničkog sveta njihove profesije ostaju lišene smisla. Otuda potreba za spajanjem studija politike i pozorišta, koje buduće donosioce odluka i dramaturge treba da pripreme da svojom maštom i talentom preoblikuju stare ili stvaraju nove temelje političkog zajedništva odupirući se tako razornim tendencijama epohe.

Rad će biti podeljen na četiri dela. Na početku ćemo razmotriti pitanje očuvanja zajedničkog sveta u svetlu odnosa vanrednog i normalnog stanja. Zatim ćemo ispitati odgovor koji pozorište daje na ovo granično pitanje političke misli. Nakon toga ćemo pokazati na koji način istorija evropske drame i pozorišta može poslužiti kao poligon za izučavanje genealogije politike. Konačno, u zaključku ćemo ukazati na potrebu za spajanjem studija politike i pozorišta u današnjem vremenu egzistencijalne krize.

\section{Poredak ili političko}

Veliki mislioci politike nikada se nisu mirili sa Heraklitovom filozofijom promene, koja život svodi na prirodni proces, rođenje - održavanje života - umiranje, spavanje - buđenje, glad - sitost, a čoveka na banalnu činjenicu među činjenicama ovog prolaznog sveta. Platon je svojom filozofijom promenu pokušao da obustavi, a Aristotel da je pojmi kao samoodređivanje. Problem promene postaje ključni za političke teoretičare u vremenima velikih političkih i društvenih previranja. Obrevši se baš u takvom dobu, Karl Šmit i Hana Arent stavili su svoju misao u službu spašavanja zajedničkog sveta i sledeći sasvim različite staze došli do istog zaključka: u normalnom stanju zajednički svet postepeno iščezava, u vanrednom se rađa prilika za njegovo potvrđivanje ili ponovno uspostavljanje.

\section{Normalno}

Verski ratovi između katolika i protestanata u XVI veku uvešće Evropu u epohu radikalnog odsustva smisla. U tom novom svetu za Šmita iščezava mogućnost sporazumevanja ljudi o tome šta je ispravno. U dobu ostavljenom bez neprikosnovenog tumača istine, "evropsko ljudstvo je tražilo jedno neutralno područje na kojem bi spor prestao i gde bi se ljudi mogli sporazumevati, ujedinjavati i uzajamno uveravati” (Šmit, 2001: 63). Prostor u kojem je suživot ljudi moguć uspostavlja se odozgo, odlukom koja neutralizuje i depolitizuje gorući spor epohe. Područja borbe stalno 
se menjaju, najpre je to bila teologija, potom metafizika, onda ekonomija i konačno tehnologija. "Evropsko ljudstvo svagda ide iz nekog područja borbe u neutralno područje, svagda novostečeno neutralno područje odmah opet postaje područje borbe, pa je neophodno da se potraže neutralne sfere" (ibid.: 64). Odluka kojom se tumači smisao, odluka suverena, nije arbitrarna. To je uvek odluka o predstavljanju ideje, "veličanstvene forme", zbog koje određeni narod poseduje oblik postojanja viši i razvijeniji u odnosu na prirodno postojanje bilo koje druge grupe ljudi koji vode zajednički život (Galli, 1996: 252). Ideju o poretku ne oblikuju sami građani, već ona oblikuje njih, njihove karaktere, daje njihovom zajedničkom životu dostojanstvo i uzvišenost.

Ideja o poretku nalazi se u samom temelju zajedničkog sveta. Kada ona iščezne iz misli i osećanja ljudi, onda se i njihov zajednički svet urušava. Kod Šmita uvek prvo ide zapovest, ljudi dolaze posle. Forma političkog postojanja društva proishodi iz autoritarnog posredovanja koje svoj izvor ima van domašaja dogovaranja ljudi, u svetu ideja. Međutim, nakon izlaska iz srednjevekovne epohe neposrednog prisustva smisla ideja o poretku se nikad do kraja ne ostvaruje i zato joj je uvek potrebno predstavljanje. Do nje na mahove dopire samo umetnička mašta koja se kreće u svetu slika ravnodušna prema svakodnevnom brbljanju, i to mašta onih pisaca koji nas povezuju sa izvorom politike i na taj izvor nas vraćaju (ibid.: 209). Takav je za Šmita bio Teodor Dojbler (Theodor Däubler) koji u pesmi "Das Nordlicht" svojom oblikotvornom imaginacijom izvlači nemačku zajednicu iz istorije, ali ne u budućnost, već u večnost (Schmitt, 1991).

Kao ni Platon, ni Šmit ne veruje da su građani dorasli zadatku uspostavljanja trajnog poretka. Tako i njega potraga za izvorom politike odvodi izvan postojeće zajednice, u svet ideja. Šmit, međutim, pesniku Dojbleru ne ostavlja preteški zadatak uređivanja svih odnosa u društvu prema formuli Nordlichta koja spaja nemački misticizam sa sposobnošću za formu čoveka latinske kulture. Dinamični i iznijansirani život moderne u stalnom vrenju nije moguće zakočiti u svim njegovim raznolikim aspektima, znao je to Šmit. Moguće je zaustaviti, neutralizovati, depolitizovati samo onu njegovu sferu u kojoj se odigrava odlučujući sukob vremena. Time se uspostavlja poredak, ali samo privremeno. U miru, blagostanju i građanskoj sigurnosti apsolutističke monarhije, stvorene odlukom monarha, ili demokratske nacionalne države, stvorene diktatom revolucionarnih vođa, ljudi će vremenom početi da zaboravljaju ideju o poretku, izvor politike, odluku koja ga je uspostavila. U moderni nema istine do koje bi dobacila mudrost Platonovog filozofa kralja. Zato je politika za Šmita uvek tragična. Kad-tad ideja o poretku odvojiće se od činjenične stvarnosti. Građani će onda ponovo početi da sami preispituju temelje svog političkog zajedništva, da raspravljaju o ispravnom i pravednom. Nedoraslost tom zadatku gurnuće njihovu državu na ivicu ambisa. Zajednički svet biće ugrožen. 
Iskustvo stvaranja SAD-a, buni se protiv Šmitovih zaključaka Hana Arent, uči nas da je poredak ipak moguće uspostaviti kroz uzajamna obećanja, sporazumevanje, dogovaranje zdravim razumom obdarenih ljudi (Arendt, 1990: 141-178). Međutim, otpočinjanje, utemeljenje nečeg novog uvek za sobom povlači pitanje sigurnosti i stabilnosti (ibid.: 223). Tako su i američki očevi osnivači revolucionarni momenat stvaralačke spontanosti iskoristili da ustanove upravljački sistem koji će svim potonjim generacijama Amerikanaca uskratiti mogućnost otpočinjanja nečeg novog. Zabrinutost za stabilnost je prevagnula. Duh revolucije, javna sreća i sloboda proterani su iz poretka. Politika je svedena na administraciju. Građani su izgubili priliku da u javnoj sferi vide i budu viđeni, što je vremenom vodilo letargiji, nezainteresovanosti i ravnodušnosti spram politike (ibid.: 238). Političko je svedeno na očuvanje onog postojećeg. Stvaranje novog ostavljeno je sferama nauke, umetnosti i filozofije, koje je upravljački sistem strukturno odvojio od politike (ibid.: 224). U stabilnosti poretka građani su svoje živote udobno smestili u privatnu sferu gde čovek ostaje uskraćen za mogućnost da ga drugi vide i slušaju, da učini nešto što je trajnije od života (Arendt, 1998: 58). Kako je život postajao lakši, u društvu potrošača sve je teže bilo uočiti da se čovek nalazi pod vlašću nužnosti (ibid.: 135). Život je prestao da proizvodi nešto trajno. Čovek je sveden na animal laborans, spavanje - buđenje, rađanje - umiranje, dan - noć, onaj ko uloži trud preživljava i ostaje deo prirode kroz svoju decu i njihovu decu (ibid.: 107). Heraklit je ponovo pobedio. Neprimetno je iščezao zajednički svet u kojem su američki očevi osnivači izveli jedan od najuspešnijih eksperimenata u političkoj istoriji.

\section{Vanredno}

Za Šmita je vanredno stanje opasnost i prilika za spašavanje zajedničkog sveta. Ono nastaje kada se utemeljujuća ideja o poretku otkači od činjenične stvarnosti. Tada se prostor za političko ponovo otvara. Obrevši se u Vajmarskoj Republici, zajednici čiji su se temelji urušavali u vrtlogu sukoba privatnih interesa i ideoloških pogleda na svet, Šmit prihvata zadatak koji je u Atini na sebe preuzeo Platon. Slično Platonovoj filozofskoj borbi protiv demokratije i pozorišta, nemački mislilac politike isprva pokreće parnicu protiv svih ustanova, uverenja i naučnih shvatanja postojećeg liberalnog sveta. Sve ono što se podrazumeva u politici i pravu on isprva dovodi u pitanje (Kervégan, 2011). Uverava Nemce da je parlament izgubio svoj istorijski i filozofski smisao, da ustavni sud nije pouzdan čuvar ustava, da demokratija znači homogenost, a ne zaštitu osnovnih prava. U stilu najvećih sofista Šmit koristi situaciju vanrednog, izuzetak, da pokaže relativnost, društveno-istorijsku uslovljenost svih postojećih društvenih ustanova i vrednosti. Izuzetak Šmitu pokazuje da je svet igra. Prepustiti se, pak, razuzdanosti te igre znači haos, iščezavanje onog zajedničkog što njegov narod čini političkim jedinstvom. Zbog toga Šmit traži načine kako bi se ta igra mogla zakočiti, staviti pod kontrolu, makar privremeno i makar samo 
onaj njen aspekt koji najviše ugrožava opstanak zajedničkog sveta. Odgovor pronalazi u evropskoj političkoj istoriji. U situaciji vanrednog diktator svojom suverenom odlukom podseća na zaboravljeni izvor politike ili obznanjuje novu ideju o poretku (Schmitt, 2015). Očuvanje starog poretka u rukama je komesarskog diktatora, čuvara ustava (apsolutistička monarhija), revolucionarna promena zajedničkog sveta delo je suverenog diktatora (Francuska i Boljševička revolucija), gospodara ustava. Zajednica koja ostane bez čuvara i gospodara ustava trajno iščezava sa pozornice istorije.

Šmit se, tako, protiv Heraklitove filozofije promene buni na Platonovom tragu, zajednički svet spašava diktator koji odlukom, autoritarno, odozgo, odbeglu ideju o poretku privezuje za društvenu stvarnost ili podanicima obznanjuje novu. Arent, pak, bori se protiv Heraklita nadahnuta Aristotelom, uverena da vanredno, promena znači novu priliku za čovekovo samoodređenje koju mu normalne okolnosti uskraćuju. Vanredno je prilika za čoveka da stvori nešto trajnije od života. Sve zajednice koje počivaju na društvenom ugovoru suočavaju se sa neizvesnošću ljudskih poslova i nepouzdanošću ljudi (Arendt, 1990: 244). Otuda je neizbežno da neka nova velika ekonomska kriza, ratovi ili drugi društveni potresi kad-tad probude građane uspavane blagostanjem i nateraju ih da postave pitanje smisla. Izuzetak, ono vanredno, ponovo otvara prostor za delanje (das Handeln), što znači preduzimanje nečega novog što se nije moglo očekivati iz prethodnih dešavanja, nečega neočekivanog, sa neizvesnim ishodom (Arendt, 1998: 177-178). Nepoverenje prema ljudima odvešće Platona i Šmita do zaključka da delanje znači najveću opasnost za opstanak zajedničkog sveta te da je nužno odozgo izbrisati prostor političke slobode na kome je ono moguće, zauvek i u potpunosti po atinskom filozofu ili privremeno i parcijalno po nemačkom pravniku. Za Arent, pak, delanje znači prekidanje automatizma banalnog svakodnevnog života, priliku da čovek potvrdi da je rođen da nešto novo započne, a ne da umre (ibid.: 246).

Ono što je za Šmita pretnja poretku, za Arent predstavlja priliku za besmrtna dela. Građani nisu dorasli sporazumevanju o ispravnom, uverava nas Šmitova teorija politike. "Ako se ozbiljno postavi pitanje o ispravnome onda će s obzirom na nerazmrsivu problematiku tog pitanja buknuti spor, spor na život i smrt: svoj legitimni osnov političko grupisanje na prijatelje i neprijatelje - ima u ozbiljnosti pitanja o ispravnome" (Štraus, 2001: 81). Zbog toga on građane oslobađa preteškog pitanja tumačenja smisla i prepušta ga diktatoru. Za Arent, pak, postavljanje tog pitanja u društvenoj stvarnosti zajednice prilika je da se čovek izvuče iz prirodnog lanca nužnosti i potvrdi svoju ljudskost. Razlike između dvoje mislilaca proishode iz različitog razumevanja čovekove prirode i prirode političkog te predstavljaju deo spora koji su još Platon i Aristotel obznanili. Ono, pak, isto što je Šmita i Arent naučilo njihovo vreme jeste nužnost iznalaženja načina da se pomire političko i poredak kako bi se zajednički svet sačuvao. Na tom zadatku oboje su podbacili. 


\section{Vanredno - normalno}

Ni Šmit ni Arent nisu za permanentno vanredno stanje. Anarhizam Prudona, Bakunjina ili Kropotkina im je stran. Oboje tragaju za putevima zasnivanja trajnog poretka. Ono što ih razlikuje jeste očekivanje od poretka. Dok je za Šmita samo njegovo uspostavljanje i održavanje dovoljno težak zadatak, Arent od poretka traži da obezbedi prostor za javnu sreću i slobodu.

Kako pomiriti stabilnost i duh novog, kako omogućiti građanima da učestvuju u javnom životu kao u vreme revolucije, pita se Arent. Odgovor traži u istoriji koja joj preko iskustva revolucionarnih društava u predvečerje Francuske revolucije, udruženja građana u vremenu Pariske komune 1871. godine, saveta u vremenu Mađarske revolucije iz 1956. godine, svedoči o mogućnosti pomirenja slobode i poretka. Saveti kao organi poretka u kojima se duh revolucije čuva nisu bili zamišljeni kao trenutni organi revolucije, već se činilo sve kako bi postali trajni organi vlasti (Arendt, 1990: 264). Saveti kao prostori slobode, spontani organi poretka i delanja, predstavljaju za Arent nov oblik vlasti, nov oblik političke zajednice. U današnjem svetu, pak, mogućnost spontane izgradnje novog poretka na temelju stvaralačkog delovanja građana premeštena je na bezbednu udaljenost od stvarnih političkih i društvenih pitanja. Neprekidno usavršavanje mehanizama "obeshrabrivanja demokratije" pretvorili su u SAD-u Džefersonovu ideju "elementarnih republika" u apstraktnu utopiju (Wolin, 2008). Ostavljen da iščekuje dolazak demokratije saveta, zajednički svet ubrzano iščezava.

Intelektualni pokušaj Hane Arent da osmisli u društvenoj stvarnosti utemeljeni predlog očuvanja zajedničkog sveta ostao je bez posledica po stvarni život. Teorijski odgovor do kog je ta potraga odvela Šmita biće u jednom trenutku stavljen u službu opravdanja zlehudog nacističkog poretka koji se početkom 30 -ih godina XX veka uspostavljao u Nemačkoj (Šmit, 2003). Ideju o novom poretku svojim odlukama predstavlja vođa pokreta, revolucionarni gospodar ustava, koji slabu totalnu državu pretvara u jaku totalitarnu. Granica između države i društva, vanrednog i normalnog iščezava. Pitanje tumačenja smisla, obznanjivanja izvora politike razrešava se u vođinoj glavi. Ovakvo rešenje proishodiće na kraju ne samo razaranjem zajedničkog nemačkog sveta već i najvećom nesrećom sa kojom se čovečanstvo do tada suočilo.

Najveći mislioci političkog XX veka ostali su nemoćni pred problemom očuvanja zajedničkog sveta. Ono što su nam ostavili jeste uvid da će odgovor na to pitanje pronaći onaj ko reši zagonetku uspostavljanja normalnog stanja, trajnog poretka, u kome se čuva sećanje na vanredno i zadržava prostor za političko. 


\section{Pozorište kao umetnički kontrapunkt duhu palanke}

Šta je normalno stanje?

Ono što su iz istorije naučili Šmit i Arent jeste da je stanje u kojem ljudi kroz život idu neupitani za pitanje smisla, uljuljkani u udobnu površinu sveta koji ih okružuje, stanje u kojem zajednički svet postepeno iščezava. Prepuštajući se onome činjeničnom, vidljivom, što oko njih postoji, sa prezirom odbacujući nepoznato, nedokučivo, tajanstveno, ljudi se prepuštaju vlasti “duha palanke” (Konstantinović, 2006). To za život znači "nerazrješivu smetenost u besmislenom kauzalnom slijedu, životarenje $u$ besplodnoj blizini zemlje i daljini neba, nužno ustrajavanje i nemogućnost samooslobođenja iz okova puke materijalnosti” (Lukač, 1990: 45) Palanka ne trpi izlete u nepoznate svetove u koje maštu zove pozorište. Duh palanke iz glava i duša ljudi istiskuje Šmitovu ideju o poretku, briše sećanje na izvor politike. Palanka je "svet zaleđenog racionalizma", to je "star i iscrpen svet" (Konstantinović, 2006: 60). Palanku kao pozitivističko načelo dana koje se suprotstavlja načelu noći kao "tajanstvu otvorenog" (ibid.: 38) naslikao je Šmit u distopiji o narodu naučnika koji čak i najtrivijalnije svakodnevno zbivanje zapisuju u dnevnike nastojeći time da život scijentifikuju i uključe se u lanac istorije (Galli, 1996: 189-191). Palanka, kao završeni, unapred predviđeni svet, ne prihvata nikakvu transformaciju činjenica (Konstantinović, 2006: 37), te stoga ne ostavlja prostor za spontano, stvaralačko delanje koje priziva Arent. Utoliko uspostavljanje vlasti duha palanke ide uporedo sa iščezavanjem zajedničkog sveta. To se može desiti u stanju radikalne izolacije gde se niko više ne može složiti ni sa kim, ali i onda kada je zajednički svet viđen iz samo jednog ugla i u kome je čoveku dozvoljeno da se predstavi u samo jednoj perspektivi (Arendt, 1998: 58).

Palanka je stanje normalnog lišeno sećanja na vanredno. To je stanje u kojem društvo očekuje od svojih članova određeni vid ponašanja, nameće im bezbrojna pravila i norme nastojeći da ih normalizuje, da isključi svako spontano delanje i izvanredne rezultate (ibid.: 40). Palančanin je animal laborans, čovek zapleten u lanac prirodnih nužnosti koji je odustao od veze sa zajedničkim svetom. Čovek prepušten vlasti duha palanke nije dorastao Heraklitovom problemu promene ni u sopstvenom životu ni u političkom životu zajednice. On prolaznost infantilno ignoriše. Smrt i život u palanci postaju banalne činjenice. Ukidajući zajednički svet, koji životu pojedinca kao delu skladne celine daje viši smisao ili mu pruža priliku da rečima i delom zasluži besmrtnost, duh palanke briše prostor za politiku. Palanačka politika zakleta trajanju trivijalnog, postojećeg, činjeničnog, pretvara se u "vašar u režiji dosade" (Konstantinović, 2006: 150). Duh palanke ne ostavlja mesta ni za tragediju (ibid.: 21). On ukida zajednički svet u kojem se može ispričati pozorišna priča o pobuni tvoračke, tragične subjektivnosti protiv poretka. 
Stanje prevlasti duha palanke odgovara stanju smrti polisa koje je Euripid sa Bakhama prikazao. To stanje označava postepeni pad u varvarstvo omlitavljeno materijalnim blagostanjem i građanskom sigurnošću. Ono teži da ukine prostor za politiku, tragediju i pozorište. Zbog toga se pozorište, poput Šmita i Arent, i buni protiv njega. Čini to suočavajući gledaoce sa ambisom vanrednog.

\section{Vanredno}

Pozorište je nespokoj za duh palanke. Ono gledaoce dovodi u granično stanje, $u$ kojem je stari identitet odbačen, a u novi se još uvek sumnja (Fischer-Lichte, 2002: 1-7). Služeći kao njihovo "magično ogledalo" (ibid.: 2), glumac gledaocima pruža priliku da započnu igru sa identitetima od koje ih odvraćaju brige svakodnevnog života.

Izuzetak ima otkrivajući karakter zahvaljujući kome čovek dolazi do svesti o svojoj posebnosti. Utoliko su situacije životnih kriza izazvane bolešću ili suočavanjem sa smrću, trudnoća, rođenje, brak, prelazak u fazu zrelosti ili starosti, sezonske promene, najveći neprijatelj duha palanke. Ući u takvo granično stanje znači nadviti se nad provaliju zapitanosti nad smislom. Tada odgovori koje diktiraju porodica, društvo, običaji ili tradicija više nisu dovoljni. Pozorište ima zadatak da gledaoce suoči sa nekim od tih graničnih iskustava dovodeći u pitanje njihova postojeća uverenja, predrasude, shvatanja i verovanja. To, pak, ne znači da gledalac iz pozorišta uvek odlazi sa formalno promenjenim identitetom, za razliku od životnih situacija velikih kriza koje čoveka nužno menjaju. Promena identiteta, dakle, nije svrha pozorišne predstave. Umetnička teatarska izvedba zadovoljava se time da gledaoca isprva dovede u granično stanje uznemirenosti, uzbuđenosti, te da mu onda kroz smiraj, pročišćenje pruži priliku da makar na trenutak zaviri dublje u tajnu života u zajednici.

Kako bi joj omogućilo da doživi neobične stvari, pozorište mora podstaći publiku na maštanje. Samo odlazak u takvo pozorište može značiti beg od duha palanke. Izvlačeći gledaoce iz normalnog stanja, pozorište pravi zemljotres u njihovim glavama i dušama. Ono im pruža priliku da postanu nešto više od animal laboran$s a$, pukih prirodnih činjenica prolaznog sveta. U dobu lišenom neprikosnovenog tumača istine zbunjenost, nespokoj, predstavlja osnovno stanje od kog ljudi pokušavaju da pobegnu sledeći vladajuća društvena uverenja o tome kako treba živeti, o poslu, ljubavi, sreći, braku, porodici. Gurajući ih u stanje egzistencijalne krize, pozorište gledaoce vraća u stanje začuđenosti, zbunjenosti, nemoćne zapitanosti nad smislom.

Veliki dramski pisci koristili su različite načine da publiku iz normalnog prevedu u stanje vanrednog. Tako Šekspir (William Shakespeare, 1564-1616) u komediji San letnje noći Engleze s kraja XVI veka suočava sa neobičnom situacijom u kojoj 
četvoro mladih ljudi beži od normalnog, u kojem se atinski zakon očeva isprečio njihovim ljubavnim željama, u vanredno, u šumu gde će uzimanje čarobnog napitka razobručiti njihovu seksualnu požudu uvlačeći ih u uzbudljivu igru menjanja uloga i identiteta (Shakespeare, 1994). Tirso de Molina (Tirso de Molina, 1579-1648) gurnuće Madriđane svog vremena u ambis vanrednog prikazujući im na pozorišnim daskama Don Žuana, zavodnika, pojedinca koji svojim obmanama, lažima i prepuštanjem vlasti požude u pitanje dovodi zakon časti na kojem počiva društveni poredak (De Molina, 2001). Svojim komadom Dobra duša iz Sečuana Breht (Bertolt Brecht, 1898-1956) će izvući publiku prve polovine XX veka iz stanja normalnog izvodeći za nju pozorišni eksperiment koji sa pretenzijom na empirijsku neumitnost prirodnih nauka pokazuje da u građanskom društvu čak i po prirodi najbolji čovek ne može ostati dobar.

\section{Vanredno - normalno}

Za argumentaciju koja se razvija u ovom članku od presudne je važnosti uvid da teatar predstavlja vrstu kulturnog izvođenja koje podstiče stvaranje, samooblikovanje i preobražaj identiteta (Fischer-Lichte, 2002). "U pozorištu se uvek radi (u kulturnom smislu) o stvaranju identiteta i promeni identiteta" (ibid.: 2). Istoričari drame došli su do ovog zaključka koristeći se istraživanjima antropologa i njihovim razumevanjem procesa promene identiteta kao posledice prolaska kroz granične, "liminalne", životne situacije. U stvarnom životu proces preobražaja identiteta prouzrokovanog egzistencijalnom krizom odvija se kroz tri osnovne faze (ibid.: 3). U prvoj fazi, fazi odvajanja, dolazi do distanciranja od svakodnevnog života, društvenog miljea, političkih i istorijskih prilika. Nakon toga sledi faza preobražaja u kojoj se čovek dovodi u granično stanje, stanje između svih mogućih stanja. To mu omogućava da isproba najrazličitije uloge sve dok ne postane spreman da preuzme novi identitet. Na kraju sledi faza inkorporacije, povratka u društvo sa promenjenim identitetom.

Proces koji se u stvarnom životu dešava kao posledica velikih kriza pozorište premešta u svet stvoren umetničkom uobraziljom. U tom umetničkom svetu, autonomnom u odnosu na onaj vidljivi, pojavni, činjenični svet palanke, kroz graničnu situaciju prolaze glumci u svojim ulogama sledeći najrazličitije puteve koje diktira maštovitost i nadarenost dramskog pisca. Preobražaj koji se odigrava na sceni preneće se u misli i osećanja publike samo onda kada umetnici svojim talentom i umećem uspeju da posetioce pozorišta izvuku iz običnog, svakodnevnog, rutinskog i prenesu u svet predstave. U tim retkim prilikama teatar postaje mesto koje gledaoce može uvući u igru sa sopstvenim identitetima, pa ih čak i podstaći na životne promene.

Faza inkorporacije kao povratak iz vanrednog u promenjeno normalno stanje, oslobođeno duha palanke, predstavlja pozorišni doprinos očuvanju zajedničkog 
sveta. U umetničkom svetu Šekspirovog komada ona se odnosi na vraćanje dva para iz šume u društvo. Ljubavnici su u šumi preko noći od dece postali odrasli ljudi. Njihovi odnosi prerasli su od prolazne dečje zaljubljenosti u trajnu ljubav. Promenilo se i društvo u koje se vraćaju. Vladar Atine odustaje od prvobitne odluke, stavlja se iznad tradicionalnog zakona očeva i dopušta mladima da sami izaberu svoje supružnike. Tada još uvek živa vera u mogućnost spašavanja zajedničkog sveta, koja će se sa komadom Kralj Lir ugasiti, vodi Šekspira da gledaocima naslika mogućnost usavršavanja društvenog poretka. Čak i pred smrt De Molinin Don Žuan odbija da se pokaje pred Bogom zbog svojih greha. U zajedničkom svetu Španaca XVI veka oblikovanom maštom dramskog pisca veliki zavodnik ne predstavlja dopadljivog društvenog buntovnika. De Molinin Don Žuan doživljava zlehudu sudbinu čoveka koji je zbog svoje nestalne prirode prokockao večno spasenje na nebu. Tako uznemireni Madriđani iz pozorišta odlaze sa nespokojem u srcu rešeni da ubuduće kontrolišu svoju požudu i poštuju kodeks časti kao temelj njihovog zajedničkog sveta. Nasuprot njima, gledaoci Brehtovog komada u XX veku napuštaju pozorište uvereni da upravo njima pripada istorijski zadatak radikalne promene društva $i$ njegovih ustanova koje ne dopuštaju dobroj Kineskinji iz Sečuana da bude dobra. Dok Molina postojeći poredak čuva od promene umetnički obznanjujući njegove temeljne vrednosti, Breht gledaocima ostavlja zadatak da po povratku u društvo sami stvaraju novi zajednički svet u kojem će predstava o dobroj duši iz Sečuana dobiti srećan kraj. ${ }^{5}$

Dela velikih dramskih pisaca vraćaju nas uvek na temeljno pitanje političke misli, na pitanje izvora političke i ljudske slobode. U načinu na koji su oni rešavali zagonetku odnosa poretka i promene ogledaju se različiti odgovori koje je njihovoj mašti šaputalo vreme čiju su istinu svojim instinktom uspevali da odgonetnu. Umetnička pobuna protiv prolaznosti života i shvatanja da je čovek ono banalno što vidimo postavila je problem promene u srž dramskog i pozorišnog stvaralaštva. Neki od velikih pozorišnih stvaralaca promenu zajedničkog sveta pokušavali su da zauzdaju, rasvetljavajući svojim talentom značaj utemeljujuće ideje poretka za život pojedinca. Drugi su publiku estetski obrazovali pripremajući je da prihvati dolazak nekog budućeg zajedničkog sveta i njegovih vrednosti. Treći su je podsticali na revolucionarnu pobunu protiv postojećih društvenih normi i političkih ustanova i davali joj smernice za izgradnju novih. Konačno, neki od njih samo su tužno obelodanjivali iščezavanje zajedničkog sveta u kojem život pojedinca može zadobiti viši smisao.

${ }^{5}$ Dela koja su navedena u ovom odeljku služe isključivo u svrhu ilustracije teze o prenošenju napetosti između vanrednog i normalnog stanja iz društvene, istorijske i političke stvarnosti u umetnički svet teatra. To je razlog zbog kog sam izbor dramskih pisaca može delovati nasumično i nedovoljno obrazloženo. U nastavku teksta sledi sistematičnija razrada teze o dramskim komadima kao odrazu temeljnih političkih problema različitih epoha evropske istorije. 
Sada ćemo se otisnuti na kratku plovidbu kroz istoriju evropske drame u potrazi za primerima koji potkrepljuju naše shvatanje o pozorišnim stvaraocima kao čuvarima zajedničkog sveta.

\section{Potraga za izvorom politike $u$ istoriji evropske drame i pozorišta}

Evropsko dramsko pozorište čiju je smrt najavio Euripid sa svojim Bakhama ponovo će oživeti tek u srednjem veku (Fischer-Lichte, 2002: 33-49). Bilo je to doba u kojem je zajednički svet čuvala Katolička crkva, kao posrednik u metafizičkom dualizmu uspostavljenom nakon čovekovog progona iz raja (Galli, 1996: 235). Crkva je bila ona veličanstvena forma za kojom je Šmit tragao, forma koja u sebi sadrži svoje poreklo. U epohi neposredno prisutnog smisla, ideja o poretku udobno se smestila u mislima i dušama ljudi. Funkcija pozorišta u tom vremenu svela se na podsećanje ljudi na poreklo, izvor njihovog bezbrižnog zajedničkog sveta. Uzimajući vodu sa tog izvora, ponekad na liturgiji, ponekad u ispovedaonici, a ponekad u pozorištu, ljudi su se napajali odgovorima na sva važna pitanja života i smrti. Materijal za predstave uzimao se isključivo iz Biblije. Nije ostavljan ni najmanji prostor individualnoj kreativnosti. Sve uloge u liturgijskim dramama igraju sveštenici. Glumci ne glume radi zabave, već u slavu Hrista. Najpopularniji komad zove se Pasijska igra i traje četiri dana. Prvog dana na sceni se prikazuje stvaranje sveta sve do poslednje večere; drugog dana gledaoci posmatraju poslednju večeru, privođenje Hrista, njegovo sučeljavanje sa Pilatom i Kajafom; treći dan posvećen je sceni razapinjanja na krst i polaganja Hristovog tela u grob; poslednjeg dana gledaocima se prikazuje vaskrsenje.

Pasijska igra izvodiće se sa velikim uspehom sve do XVI veka. Kada je Luter u pitanje doveo posredničku ulogu Katoličke crkve između Boga i sveta grešnika, dotadašnja ideja o poretku odlutala je iz glava i duša ljudi koje od tad nastanjuje metež, nemir i nespokoj (Fromm, 1941). Ostavljen bez vrhovnog tumača smisla, dotadašnji zajednički svet survao se u provaliju verskih i građanskih ratova. Poredak će ponovo uspostaviti apsolutistički monarh svojom odlukom kojom se depolitizuje i neutralizuje područje gorućeg spora epohe, teologija. Odvajanje odluke o ispravnom u religijskom sporu između katolika i protestanata od zahteva posvađanog društva omogućilo je čoveku da u miru svoje privatne sfere odnos prema Bogu uređuje prema zahtevima sopstvene savesti. Uspostavljanje apsolutističke monarhije povratilo je mir, stabilnost i materijalni prosperitet. Pozorište koje će u Francuskoj Luja XIV u jednom trenutku zauzeti važno mesto u životu dvorskog društva biće stavljeno u službu slavljenja monarha i neprikosnovenosti njegove odluke o tumačenju smisla. Uživljen u ulogu vrhovnog režisera čija odluka u harmoničnu celinu sklapa pojedinačne ambicije, želje, interese i težnje podanika, Kralj Sunce u julu 1668. godine organizuje festival pod nazivom "Noć iluzija". Gosti, za tu priliku po- 
zvani u Versaj, idu po sobama, istražuju, nailaze na iznenađenja, nesvesni da igraju uloge koje im je kralj namenio. Ova neobična predstava u monarhovoj režiji svedoči o njegovom talentu da sebe i državu predstavi na sceni (Fischer-Lichte, 2002: 98). Kraljeva prolazna ljubav prema dramskom pozorištu, koja je trajala petnaestak godina pre nego što je prešla na operu, poslužiće Molijeru (Jean-Baptiste Poquelin, 1622-1673) da svoje delo postavi u sam centar kulturnih zbivanja. U pozorištu kome je sedište za "idealnog posmatrača" bilo rezervisano za kralja, Molijer će Francuzima kroz sudbinu nesrećnog Mizantropa (Molijer, 1935) na umetnički način obznaniti ideju o apsolutističkom poretku.

Kako bi pozorišnu publiku oslobodio vlasti duha palanke i podigao je do stanja vanrednog, veliki komediograf koristi razorno sredstvo u doba lukave uzdržanosti: iskrenost $\mathrm{u}$ ispoljavanju mišljenja i osećanja glavnog junaka u predstavi, Alzesta. Rešen da kao "častan čovek" nikad ne izrekne "reči koje neće od srca poteći", Alzest dovodi u pitanje civilizacijsku normu honnête homme na kojoj počiva monarhističko društvo (Rochefoucauld, 1935). U društvu u kojem status pojedinca više ne određuju njegova dela već kraljeva volja, položaj, ugled i čast zaslužuju se dvorskim intrigama, kontrolisanjem emocija, planiranjem na duže staze, veštim prikrivanjem osećanja i mišljenja, prepoznavanjem finih nijansi u rečima, gestovima i pozama sagovornika (Fischer-Lichte, 2002: 102). Svoj "bes protiv običaja doba" Alzest nezgrapno ispoljava ismevanjem neprirodnog soneta netalentovanog pesnika, neprihvatanjem lažnog i naglog prijateljstva koje svoje naklonosti isuviše otvoreno iskazuje i nipodaštavanjem ljudi čija se reč na dvoru sluša. Pravu meru Alzestove pobune protiv postojećeg poretka, pak, obelodanjuje njegov odnos prema Selimeni, za čiju se naklonost njegova vrlina bori protiv lukavosti i intriga tipičnih predstavnika dvorskog društva tog vremena. Naime, moglo bi se tvrditi da u Molijerovom komadu Selimena predstavlja samog monarha Luja XIV, koji društvo okuplja oko sebe i svakome daje ponešto. Fina ravnoteža koju Selimena održava sa velikom umešnošću u svom salonu upadljivo podseća na uslove koje uspostavlja Luj XIV kako bi održavao poredak na dvoru (ibid.: 111). Od njene odluke zavisi društveni status i život udvarača koji je okružuju. Mizantropova ljubomora, želja da je ima samo za sebe buni se protiv takvog poretka. Prigovarajući Selimeni, optužujući je za pritvornost i neverstvo, Alzest podriva temelje zajedničkog sveta. Kada je na kraju komada pozove da sa njim pobegne iz društva spletki i pritvornosti, kriza dostiže svoj vrhunac. Nakon toga sledi odgovor Molijerovog doba na pitanje pomirenja vanrednog i normalnog.

Društvo ne ostaje bez svog monarha. "Ja, da se odreknem sveta dok sam mlada, u pustinji vašoj da zamrem još sada?” odbija Selimena Alzestovu ponudu. Mizantrop iz društva odlazi sam. "Pokvarenost opšta suviše me vređa, hoću ljudskom društvu da okrenem leđa." Van društva, međutim, nema ko da se divi njegovoj vrli- 
ni. U svojoj pobuni protiv pritvornosti doba Alzest ne prepoznaje da je i sam zarobljenik u ulozi iskrenog bundžije. Sam odlazak iz društva samo je deo predstave koje je glavni junak nesvestan (ibid.: 110). Mizantrop, koji želi da uspostavi nadmoć u svim prilikama i traži divljenje zbog svoje vrline, ispada smešan. Ne mora se protiv ljudskih mana vehementno vikati na sav glas, poručuje publici Molijer. "Zašto bi nas sve to tol'ko jeda stalo da prirodi ljudskoj oprostimo malo?" pokušava da ublaži mizantropovu srdžbu njegov prijatelj Filent. On je kao i Alzest svestan ljudske iskvarenosti. "Pobeđuje onaj ko je lukaviji. Ljudi bi trebalo da budu drukčiji. Ali da li treba zbog gadosti njine da se povučemo iz ljudske sredine?" Kako ostati u društvu svestan njegovih slabosti? Umerenost i razum, norma honnête homme, oličena u Filentu, predstavljaju za Molijera rešenje te stare zagonetke. Ispraćajući gledaoce iz pozorišta u društvo sa Filentovom porukom, francuski dramski pisac dao je umetnički doprinos čuvanju zajedničkog sveta francuske apsolutističke monarhije.

U miru apsolutističke monarhije bledelo je vremenom sećanje na krvavu Vartolomejsku noć i haos građanskih i verskih ratova iz kog je društvo spasila monarhova odluka. Uljuljkani u stabilnost poretka, podanici su sve više zaboravljali njegov izvor. Neiskorenjiva ljudska radoznalost, želja za slobodom, otpočinjanjem novog, postepeno vodi stvaranju tajnih društava u kojima se raspravlja o pravičnom, dobrom i lepom (Kozelek, 1997). Isprva skrivena, skromna i kontrolisana, ljubopitljivost će do kraja XVIII veka postati razobručena i samouverena. U Francuskoj će se ona na kraju preliti na ulicu, postaviti pitanje o izvoru političkog i dovesti do krvave revolucije. Posmatranje revolucionarnih događaja u Francuskoj izazvaće kod Kanta uverenje u "moralnu obdarenost ljudskog roda" (Kant, 1974: 185).

Uveren u neumitnost istorijskog progresa ka republici slobodnih građana, veliki filozof ne priziva nasilnu revoluciju u svojoj zemlji. Politička revolucija, nasilje, teror strani su i najvećem nemačkom pesniku nadahnutom Kantovom filozofijom svrhovitog razvoja istorije, Geteu (Johann Wolfgang von Goethe, 1749-1832). Za čovekovo izbavljenje iz stanja "samoskrivljene nezrelosti" nije potrebna revolucija, već poučavanje, prosvetljivanje, bio je uveren Gete. Njegovo pozorište u Vajmaru tako ima zadatak da kultivisanu publiku estetski obrazuje, oplemeni njeno iskustvo, da je nauči da, poput Kanta i njega samog, u prirodi i istoriji prepozna ono lepo. U pozorištu zamišljenom kao mesto kultivisanja društvene elite, između gledalaca i glumaca, koji prirodu prikazuju na idealizovani način, postoji estetska distanca (Fischer-Lichte, 2002: 199). Publika odlazi na putovanja na koja se daleko od briga svakodnevnog života ne ide zarad udobnosti, već zarad učenja i zadovoljstva (ibid.: 200). U pozorištu se prikazuju velika dela svetske književnosti. Gledaoci se vode u strane zemlje, davna vremena i neobične kulture kako bi naučili da prepoznaju i ubrzaju dolazak zajedničkog sveta slobodnih i autonomnih ličnosti. Taj novi svet za Getea u stvari znači vraćanje onog starog čiji je kraj Heraklit turobno najavio, 
grčkog sveta u kojem je čovek svojim delima mogao dostići ideal samoostvarenja. U taj davni izgubljeni svet skladne pomirenosti slobode i poretka Gete gledaoce odvodi pričajući im priču o Ifigeniji na Tavridi (Gete, 1944).

Ono za šta je Alzest koristio Molijeru Ifigenija služi Geteu, naime, da publiku suoči sa situacijom vanrednog, graničnog, u kojoj se postojeći identitet društva dovodi u pitanje. Ifigenija se pred gledaocima pojavljuje kao onaj Kantov slobodni građanin s kraja istorijskog puta koji se u svetu oseća kod svoje kuće, a na probleme zajedničkog života gleda nezavisno od interesa svoje klase, konfesije, profesije ili nacije. Takav idealni građanin, čija potraga za samoostvarenjem ide s one strane običaja i postojećih odnosa moći u društvu, otvoreno se buni protiv društvenih i političkih pogleda na svet nemačkog gledaoca tog vremena. Ćerka slavnog Agamemnona, žrtvovana zarad uspeha očevog pohoda na Troju, preživela je zahvaljujući volji Toanta, vladara Tavride, koji se stavlja iznad običaja države i odlučuje da strankinju ostavi u životu. Odbijajući potom da se za Toanta uda, Ifigenija u pitanje dovodi postojeće odnose moći u društvu i neprikosnovenost zapovesti vladara. Štaviše, umesto nametanja suverene kraljeve volje silom Ifigenija od vladara Tavride dobija obećanje da će je pustiti da se vrati svojoj domovini ako se za to ikad ukaže prilika. Konačno, ne prihvatajući da sa svojim bratom, Orestom, sa Tavride pobegne i tako izneveri svog dobročinitelja Toanta, Ifigenija se suprotstavlja shvatanju da se sporovi u društvu moraju rešavati lukavstvom i nasiljem.

Dovevši prethodno u pitanje vladajuća uverenja i običaje koji sputavaju čoveka na putu samoodređenja, Gete publiku vraća u stanje normalnog pokazujući joj krajnji cilj istorijskog progresa. Umesto sile mača, strance i Toanta do rešenja spora o ispravnom vodi razgovor. Vladar Tavride na kraju odlučuje da se pridržava zadatog obećanja. Prihvata Ifigenijinu "grančicu mira ljupku, što je jača u ženskoj ruci od oružja i mača". Pušta zatočenicu da se sa svojim bratom vrati kući. Tako Ifigenija, kao "čista duša", uspeva da navede "surovog Skita" da "čuje glas istine i čovečnosti". U Geteovom komadu odnosi u društvu temeljno su promenjeni. Od Molijerove Selimene, kao umetničke slike monarha koji svojom odlukom na okupu drži dvorsko društvo pritvornosti, intriga i lukavstva, stiglo se do Geteovog vladara Tavride pred čijom "uzvišenom dušom" behu "postiđene sila i lukavstvo". Od stvarnog nemačkog društva, pak, ideal Geteove Ifigenije na Tavridi ostaje beznadežno udaljen. Publika ne uspeva da se poistoveti ni sa jednim od likova. Zbog toga iz pozorišta izlazi hladna.

Repertoar pozorišta u Vajmaru odgovarao je svetu koji tek treba da dođe (Fischer-Lichte, 2002: 200). Kako je XIX vek u Evropi odmicao, taj Geteov i Kantov budući zajednički svet postajaće sve dalji od društvene i političke stvarnosti. Industrijalizacija kapitalističkog društva ubrzano je sužavala prostor za čovekovo samoostvarenje (Polanji, 2003). Prosvetiteljski ideali sve više su bledeli. Evropljani 
su se pokazali nedoraslim da odgovore na preteško pitanje tumačenja smisla koje im je Francuska revolucija poverila. Ko sam ja? Kako treba živeti? Šta je vredno u životu? Pozorište XIX veka u Evropi postaje mesto utočišta od ovih preteških pitanja koja su se za građane otvorila u svakodnevnom životu. U društvu suočenom sa egzistencijalnom krizom pozorište preuzima ulogu čuvara duha palanke. Na repertoarima nema dela velikih pisaca, poput Bajrona, Klajsta, Šelija, De Misea, koja uspevaju da ogole razdiruće društvene protivrečnosti doba (Fischer-Lichte, 2002: 205). Umesto toga na pozorišnim daskama se prikazuju trivijalne melodrame u kojima srednja klasa traži predah od preteških životnih dilema. U bečkom Burgerteatru 1820-ih i 1830-ih godina ismeva se mladi evropski intelektualac bajronovskog tipa koji je u neskladu sa sobom i svetom (ibid.: 225-230). Glumci se na sceni rugaju buntovničkoj ličnosti u iluzornoj potrazi za samoodređenjem. Predstave slave postojeće društvo, porodicu i običaje, koji evropskom čoveku izgubljenom u hladnom lavirintu potrage za identitetom pružaju toplinu i sigurnost. Duh palanke će sa pozorišnih dasaka biti oteran tek krajem XIX veka, kada dosadna banalnost više ne bude u stanju da prikrije iščezavanje zajedničkog sveta. Umiranje zajedničkog sveta koji je ostao bez svoje ideje o poretku obznaniće tada veliki Euripidovi naslednici Ibzen, Strindberg i Čehov.

Vrativši suštinska pitanja društva na pozorišnu scenu, tri velikana istovremeno su publici tužno saopštila da na njih nema odgovora u svetu koji su poznavali. U svojim komadima Ibzen (Henrik Ibsen, 1828-1906) razotkriva laž porodičnog života, predstavljajući publici neiskrenost i licemerje kao jedini izlaz u vremenu u kojem članovi familije više nisu u stanju da žive u skladu sa patrijarhalnim idealom koji im društvo nameće (Ibzen, 1986). U Putu za Damask Strindberg (Johan August Strindberg, 1849-1912) gledaocima priča priču o pesniku uverenom u svoju posebnost koga sa puta samoostvarenja bezpovratno odvlače strahovi i dela iz prošlosti, ostavljajući ga zauvek zarobljenog u lavirintima podsvesti. Laž palanačkog duha XIX veka da porodica za čoveka znači bezbrižno utočište i da čovek može biti srećan, kreativan i izabran zahvaljujući svojoj profesiji, umetničkoj ili naučničkoj, ogoliće najubedljivije Čehov (Anton Pavlovič Čehov, 1860-1904). U njegovom Ujka Vanji (Čehov, 2008) porodična ljubav samo je izgovor za slabost, niko se ne ostvaruje kao ličnost, niko ne pronalazi svoj životni put. Sebičnost i zaokupljenost sopstvenim ambicijama, željama i strahovima sprečava likove u komadu da uspostave vezu sa zajedničkim svetom, da osete empatiju, da razumeju drugog. Niko nije srećan. Nije to ni netalentovani profesor istorije umetnosti, ni njegova lepa mlada žena isuviše lenja da od života zatraži nešto više od materijalne udobnosti, ni njegova ćerka pomirena sa turobnošću života, ni njegov šurak, slabić, koji ostaje zaglavljen u besmislenosti palanačkog života, ni mladi doktor koji od ljudi očekuje isuviše pa su mu se zgadili. Suočeni na kraju komada sa licem ujka Vanje tužno zagledanim 
u životnu bezizlaznost, gledaoci vide zlehudu sliku vremena koje se još nije odlučilo. Čehovljevi komadi slikaju svet koji je ostao bez svoje stare utemeljujuće ideje dok za novom još uvek beznadežno traga. Nema povratka u normalno, uređeno, stabilno. Egzistencijalna kriza, čovekova bespomoćna zapitanost nad smislom, na sceni je samo ogoljena i lišena zaštite palanačkog duha. Gledaoci iz pozorišta odlaze sa strepnjom i nemirom u duši.

Prvi svetski rat, velika politička i ekonomska kriza koja je ratu prethodila i sledila ga, gurnuli su evropska društva u stanje razuzdane igre sa identitetima. U Evropi počinje grčevita društvena potraga za formom političkog postojanja. U nju se uključuju i veliki dramski pisci čija se umetnička mašta obrela u vremenu koje je njihovim likovima uskraćivalo priču. Ako u životu više ne postoji nikakva forma, čvrst oslonac, pouzdani sistem vrednosti koji bi razgraničio dobro od zla, časno od nečasnog, pravično od nepravičnog, kako ispričati priču o likovima koji odnekud dolutaju u piščevu maštu? Šta znače njihova dela i reči u odsustvu zajedničkog sveta koji bi o njima mogao suditi? Pirandelov (Luigi Pirandello, 1867-1936) odgovor u komadu Šest lica traži pisca predstavlja najveći pozorišni skandal izveden na evropskim pozornicama prve polovine XX veka (Pirandelo, 2011). "A zašto ne bih - rekao sam sebi - prikazao ovaj posve neobičan slučaj jednog pisca koji odbija da podari život svojim likovima rođenim u njegovoj mašti i slučaj ovih likova koji, pošto je u njih već udahnut život, ne mogu da se pomire sa tim da će ostati izvan sveta umetnosti" (ibid.: 9).

U Pirandelovom komadu radikalizuje se egzistencijalna kriza u kojoj se društvo već nalazi u stvarnom životu. U njegovu maštu dolutalo je šest likova u potrazi za prilikom da svetu obznane dramu koja se odvija u njima samima. Otac, majka, pastorka, sin, dečak i devojčica dolaze u pozorište, prekidaju probu i od reditelja i glumaca traže da njihovu životnu priču postave na scenu. To se ispostavlja kao pretežak zadatak. Sveta zajedničkih uverenja, verovanja i običaja više nema. Delo više ne određuje onog koji dela kao u Aristotelovom shvatanju tragedije. Pirandelovi likovi ne prihvataju da budu ono što su u životu činili. Za to što je otac u jednom trenutku oterao svoju ženu od kuće, a u nekom drugom svoju pastorku primorao na blud on okrivljuje prolaznu slabost. U njemu je mnogo osoba. Čovek u sebi ima potencijal za promenu, može se razvijati u bezbroj različitih pravaca. Zato otac ne prihvata da ono loše što je nekad u prošlosti učinio odredi njegov život, okameni ga u formu. U pozorištu, pak, višestrukost ličnosti koje se nalaze u svakom od nas reditelj i glumci moraju da svedu na jednu, inače je priču nemoguće ispričati. Pričajući priču o šest likova u grčevitoj potrazi za dramom, Pirandelo publici predstavlja odlučujući sukob vremena ostavljenog bez zajedničkog sveta, "sukob između života koji se neprestano kreće i preobražava i nepromenljive forme koja nastoji da ga zakoči, okameni” (ibid.: 11). 
Društveni nered i haos Pirandelo prenosi na pozornicu. Svi postojeći pogledi na svet se relativizuju. Pokušaji glumaca da igraju neku od šest uloga ispostavljaju se kao promašaji. Naime, glumci čine jedino što mogu, uživljavaju se u likove pokušavajući da što vernije prikažu njihova dela, mišljenja, osećanja. Time se međutim likovi zamrzavaju, samo jedna od bezbroj životnih mogućnosti u njima ostvaruje se na uštrb svih ostalih. Šest likova u potrazi za dramom to doživljava kao lažno. Ne pristaju da njihovi životi budu falsifikovani. Ni između njih i reditelja nema sporazuma i dogovora. Na sceni nastaje potpuni metež. Onda Pirandelo publici saopštava svoje umetničko rešenje zagonetke odnosa između poretka, kao nepromenljive forme, i političkog, kao spontanog, životnog, radoznalog i nesputanog koje prekoračuje granice.

Kao Karl Šmit, i Pirandelo shvata nužnost zauzdavanja društvene igre. Njemu kao i nemačkom pravniku iskustvo govori o nemogućnosti uspostavljanja poretka putem uzajamnih obećanja i sporazumevanja ljudi. Stoga mora postojati neka sila koja će odozdo društvu podariti formu i tako uspostaviti kontrolu nad relativizujućim haosom. U komadu Šest lica traži pisca ulogu diktatora na sebe preuzima reditelj. U jednom trenutku on odlučuje da sprovede predstavu do kraja, prekida jalove i zamorne rasprave između glumaca i likova i počinje da zapoveda. Haos je moguće kontrolisati kroz umetnost, na Platonovom tragu publiku uverava Pirandelo. Samo umetnost može iznedriti formu kojom se život pojedinca i njegove zajednice spašavaju od besmisla prolaznosti. "Sve što živi, samim tim što živi ima formu i upravo stoga mora da umre; osim umetničkog dela koje živi zauvek, budući da je forma" (ibid.: 19). Formu koju će u njegovom komadu posvađanim glumcima i likovima dati reditelj, posvađanom italijanskom društvu Pirandelovog doba u jednom trenutku nametnuće vođa fašističkog pokreta Musolini. Zbog toga Pirandelo ushićeno odobrava "estetski fašizam" vođe koji, smešten iznad politike i brbljanja u parlamentu, društvu obznanjuje i nasiljem sprovodi svoju viziju političkog zajedništva (Puchner, 2010: 103-104). Politika je poput umetnosti. Materijal sa kojim vođa stvara svoju umetnost jesu probuđene mase. On ih oblikuje, usmerava. Pozorište će tako biti stavljeno u službu gospodara ustava, suverenog diktatora koji postojeće društvo, njegove ustanove i uverenja revolucionarno menja prema zahtevima sopstvene uobrazilje. Novi svet koji je Duče u Italiji stvarao trajaće samo do konačnog poraza fašista u Drugom svetskom ratu. Proces izgradnje novog poretka i smisla u Italiji i Evropi koji je tada započet na ratnim ruševinama traje i danas i ima neizvestan ishod. 


\section{Potreba za spajanjem studija politike i pozorišta - studenti dramaturgije i političkih nauka kao budući čuvari zajedničkog sveta}

Očuvanje zajedničkog sveta predstavlja centralni problem sa kojim se veliki politički mislioci i pozorišni stvaraoci suočavaju vekovima. To je osnovni zaključak do kog nas je doveo ovaj rad. U radu smo pokazali da zadatak očuvanja zajedničkog sveta stoji u neraskidivoj vezi sa problemom odnosa normalnog i vanrednog stanja, kao odnosa između trajnog, poretka, forme koja koči i ograničava, i političkog, kao stvaralačkog, spontanog i nepostojanog života koji se zauzdavanju opire, a granice prekoračuje. Videli smo da se taj problem za velike dramske pisce postavljao na različite načine u zavisnosti od epohe i pokazali smo na koji je način njihova umetnička mašta sa njim izlazila na kraj. Pitanje koje na kraju postavljamo jeste kakav značaj za naš današnji svet imaju ovi zaključci sakupljeni na putovanju kroz istoriju evropske drame i političke misli.

Građani danas u Evropi žive u vremenu egzistencijalne krize koje u mnogo čemu podseća na ono čiju su istinu svojim umetničkim darom svetu preneli Čehov, Strindberg i Ibzen. Zajednički svet u Evropi vekovima zatvoren u okvire pojedinačnih nacionalnih država urušio se. Novi još uvek nije stvoren. Ono, pak, novo što naše vreme donosi jeste nesposobnost društva "da svoja zaista temeljna pitanja i osnove, koji su snažno uzdrmani, i 'dramatizira' kao neizvesne” (Lehman, 2004: 340). Oni pozorišni autori koji se osmele da se uhvate u koštac sa političkim problemima, da tematiziraju društvene sukobe, uglavnom preuzimaju zastarele, prevaziđene šablone nacionalizam - kosmopolitizam, levica - desnica, kapitalizam - komunizam, ostajući daleko od stvarnih izazova našeg vremena. Trivijalnost takvih pokušaja uzrokovana je nesposobnošću da se prepozna iščezavanje zajedničkog sveta bez koga, kao što je u ovom radu pokazano, ne može biti ni priče, drame, ideoloških sukoba, borbe pojedinca sa poretkom. "Dubina, opseg i konzekventnost tematiziranja sukoba pokazuju kako stoji s 'ljepilom', solidarnošću ili pak dubljim simboličkim jedinstvom društva, koliko si drame ono takoreći može priuštiti” (ibid.). U svetu koji je ostavljen bez starog "ljepila" dok se za novim još uvek traga, prostor za dramsko pozorište sve ubrzanije se sužava. Drama ostavljena na milost i nemilost piscima koji svoj oslonac pronalaze $u$ vrednostima starog sveta seli se $u$ sferu dosade i banalnosti.

Iščezavanje prostora za dramsko pozorište znači istovremeno i iščezavanje prostora za politiku. U evropskom svetu u kojem drama "postaje jezgrom više ili manje banalne masovne zabave" (ibid.) političari postaju šrafovi bezličnog upravljačkog mehanizma odvojeni od zahteva društva (Mair, 2013). U današnjoj Evropi političari podsećaju na aristokratiju uoči Francuske revolucije, koja je, iako je odustala od svojih društvenih funkcija, zadržala sva prava i privilegije. Upravo je parazitska pozicija današnjih sistemskih političara, kao nemoćnih posmatrača ubrzanog 
urušavanja glavnih tekovina države blagostanja, ono što podstiče bes i rasplamsava nezadovoljstvo u glavama ljudi (Bonelli, 2019). Poput besplodnih dramskih pisaca oslonjenih na proizvoljno izabrane parčiće razbijenog društvenog ogledala vrednosti, političari bezuspešno pokušavaju da navedu građane da se opredele između potrošenih ideoloških alternativa koje je naše vreme obesmislilo. To za posledicu ima sporadično prelivanje na ulice velikih evropskih gradova razobručenog, nekontrolisanog društvenog besa, odustalog od potrage za novom formom političkog postojanja, rešenog samo da ostatke zajedničkog sveta sravni sa zemljom (Halimi, 2019).

U Pirandelovom komadu Šest lica traži pisca jedini lik koji ne traži dramu, priču, smisao, jeste lik majke. "Ona nema nikakvu sumnju da je već živa; niti joj je ikada palo na pamet da se pita kako i zašto i na koji način to jeste" (Pirandelo, 2011: 15). Majka je isključivo vezana za svoj prirodni položaj majke, "ona i ne živi kao duh", nije ni svesna da je lik, što ne znači da ona to nije (ibid.: 17). Živimo li mi u vremenu u kom su ljudi, poput majke iz Pirandelovog komada, tupo, poput životinja, odustali od potrage za svojom pričom? Ono što potragu za pričom danas usložnjava, čini njen ishod neizvesnijim nego u Pirandelovo vreme, jeste iščezavanje granice između vanrednog i normalnog. Za razliku od prethodnih epoha analiziranih u ovom radu, izgleda da duh palanke i vanredno danas uspevaju da pronađu zajednički jezik. Goli život majke iz Pirandelovog komada, sveden isključivo na reproduktivnu, životinjsku, dimenziju, preselio se iz stanja vanrednog u normalno. "Od ključne je važnosti da se, paralelno sa procesom putem koga izuzetak svuda postaje pravilo, prostor namenjen golom životu, i inicijalno smešten na margine poretka, progresivno počinje preklapati sa političkim prostorom, dok isključivanje i uključivanje, spoljašnje i unutrašnje, zoe i bios, pravo i činjenice ulaze u zonu trajne nerazlučivosti” (Agamben, 2013: 22). Politizacija golog života podrazumeva izgradnju novog ili obnavljanje temelja starog zajedničkog sveta. To postaje gorući zadatak doba za političke delatnike i dramske pisce. Neuspeh znači potonuće u varvarstvo i ponovno iščezavanje drame i politike koje je Euripid jednom davno već bio ispratio sa evropske pozornice.

Zastrašujuće obrise "sveta bez ljudi" predstavio je 2018. godine beogradski pozorišni festival Bitef. Pomaljanje tog turobnog sveta ide paralelno sa tehnokratskim procesom stvaranja politički ujedinjene Evrope bez Evropljana (Kovačević, 2017). Da li je, pak, trajno proterivanje politike, pozorišta i drame iz života ljudi neumitnost? Da li današnje Evropljane samo gubitak materijalne udobnosti može na kratko premestiti iz stanja tupe ravnodušnosti u stanje razobručenog divljeg besa? Zaključci do kojih smo došli u ovom radu bune se protiv ove sumorne prognoze. Oni nam govore da je temeljni zadatak politike i pozorišta, zadatak očuvanja zajedničkog sveta, uvek isti, samo se menjaju istorijske okolnosti u kojima on iskrsava pred imaginaciju političkih mislilaca i dramskih pisaca. Rad nam takođe govori da 
veliki politički mislioci i dramaturzi nikada nisu odustajali od borbe sa Heraklitovom filozofijom promene. Darovitost umetnika odbijala je da prihvati da njihov svet naseljavaju ljudi svedeni na banalne činjenice. Ni Platon, ni Eshil, ni Molijer nisu uspevali da jednom za svagda zauzdaju promenu koja je na kraju ipak porazila njihove svetove, ali njihovi naslednici od borbe nikada nisu odustajali. Verovali su da žive među ljudima koji tragaju za pričom, dramom, koje bez zajedničkog sveta ne može biti.

Ukoliko danas ipak živimo u svetu ljudi koji su trajno odustali od potrage za smislom, onda i studije politike i dramaturgije gube razlog svog postojanja. Istorija evropske drame i političke misli upozorava nas na ishitrenost takvog zaključka. Postoji, međutim, i drugi uzrok zbog kog fakulteti na kojima se obrazuju budući dramaturzi i politički delatnici gube svrhu, a čije se otklanjanje nalazi u dometu naših mogućnosti. Naime, u radu smo pokazali da politika i pozorište pravu priliku dobijaju tek pošto uspeju da se oslobode vlasti duha palanke. Današnja tendencija da se politička nauka svede na "nauku", koja odbacuje pitanje o ispravnom, ostaje neutralna u sukobu dobra i zla te sa preciznošću prirodnih nauka proverava svoje trivijalne "hipoteze" u svetu nepromenljivih činjenica, glavni je pokazatelj uspostavljanja vlasti duha palanke nad nastavom politike. Studenti uspavane maštovitosti, naučeni da gmižu po onom prizemnom, materijalnom, činjenično postojećem, teško će poleteti do visina borbe sa Heraklitovom filozofijom prolaznosti kao borbe za očuvanje starog ili izgradnje novog zajedničkog sveta. Bez te borbe i zajedničkog sveta u kojem se ona vodi, pak, njihova buduća profesija ostaje lišena smisla. Istovremeno, studije dramaturgije lišene nastave političke teorije ostavljaju buduće dramske pisce bez neophodnih orijentira za snalaženje u današnjem vremenu u kome su, kao i u Platonovo i Pirandelovo uzburkano doba, sva važna pitanja političke misli ponovo otvorena. Ostavljena bez pouzdanog vodiča, mašta budućih dramaturga biva prepuštena besciljnom vrzmanju po banalnoj površini društva koje ubrzano gubi sposobnost da svoju priču ispriča.

Otuda predlog za spajanje studija politike i dramaturgije u vidu zajedničkog programa posvećenog problemu očuvanja ili izgradnje zajedničkog sveta. Ono bez čega budući politički delatnik i dramski pisac ne mogu učiniti ništa značajno u svojim profesijama jesu maštovitost, talenat, oblikotvorna moć. Politička odluka i stvaranje umetničkog dela uvek predstavljaju iskorak u prostor oslobođen pravila koja pruža prethodno iskustvo. Političko i umetničko delanje kojim se od umiranja brani stari svet ili uspostavlja novi kreću se upravo u tom prostoru. Kako da svojim odlukama i stvaralaštvom dosegnu ideale pravičnog i lepog studente niko ne može naučiti. Ono, pak, čemu studije političkog u pozorištu mogu doprineti jeste buđenje osetljivosti budućih donosilaca odluka i dramaturga za temeljne političke proble- 
me epohe. Upoznajući studente sa problemom čuvanja zajedničkog sveta u istoriji evropske drame i političke misli, te studije mogu im pomoći da svojom maštom i talentom prepoznaju način na koji se taj stari problem pojavljuje u današnjem vremenu. Uvođenje studijskog programa koji bi buduće donosioce odluka i dramaturge podstakao da svoje stvaralaštvo stave u službu potrage društva za novom formom političkog postojanja moglo bi doprineti zaustavljanju erozije smisla kroz koju fakulteti političkih nauka i dramskih umetnosti danas prolaze zajedno sa politikom, dramom i pozorištem.

\section{LITERATURA}

Agamben, Đorđo. 2013. Homo Sacer. Suverena moć i goli život. Karpos. Loznica.

Arendt, Hannah. 1990. On Revolution, Penguin Books. London.

Arendt, Hannah. 1998. The Human Condition. The University of Chicago Press. Chicago.

Aristotel. 2008. O pesničkoj umetnosti. Dereta. Beograd.

Bonelli, Laurent. 2019. Pourquoi maintenant? Le monde diplomatique, br. 778, god. 66, januar.

Čehov, Anton Pavlovič. 2008. Ujka Vanja. Srpska književna zadruga. Beograd.

De Molina, Tirso. 2001. Seviljski zavodnik i kameni gost. Paidea. Beograd.

Đurić, Miloš. 1972. Istorija helenske književnosti. Zavod za udžbenike. Beograd.

Eshil. 1994. Agamemnon, u: Grčke tragedije I. Srpska književna zadruga. Beograd.

Eshil. 1994a. Okovani Prometej, u: Grčke tragedije I. Srpska književna zadruga. Beograd.

Euripid. 1994. Bakhe, u: Grčke tragedije II. Srpska književna zadruga. Beograd.

Fromm, Erich. 1941. Escape from Freedom. Henry Holt and Company. New York.

Fischer-Lichte, Erika. 2002. History of European Drama and Theater. Routledge. London i New York.

Galli, Carlo. 1996. Genealogia della politica. Carl Schmitt e la crisi del pensiero politico moderno. Il Mulino. Bologna.

Gete, J. Volfgang. 1944. Ifigenija na Tavridi. Jugoistok. Beograd.

Halimi, Serge. 2019. Quand tout remonte à la surface. Le monde diplomatique, br. 778, god. 66, januar.

Hegel, G. V. F. 1975. Istorija filozofije, sv. II. Beogradski izdavačko-grafički zavod. Beograd. 
Heraklit. 1981. Fragmenti. Grafos. Beograd.

Homer. 2002. Ilijada. Zavod za udžbenike i nastavna sredstva. Beograd.

Ibzen, Henrik. 1986. Drame. Lutkina kuća/ Sablasti/ Divlja patka. Veselin Masleša. Sarajevo.

Kant, Imanuel. 1974. Spor među fakultetima. Drugi odeljak. Spor između filozofskog i pravnog fakulteta, u: Danilo Basta (ur.): Um i sloboda. Spisi iz filozofije, prava $i$ države. Posebno izdanje časopisa "Ideje". Beograd.

Kervégan, Jean-François. 2011. Que faire de Carl Schmitt? Gallimard. Paris.

Konstantinović, Radomir. 2006. Filosofija palanke. Otkrovenje. Beograd.

Kovačević, Bojan. 2017. Europe's Hidden Federalism. Federal Experiences of European Integration. Routledge. London/New York.

Kozelek, Rajnhart. 1997. Kritika i kriza. Plato. Beograd.

Lehman, Hans-Thies. 2004. Postdramsko kazalište. Centar za dramsku umetnost/Centar za teoriju i praksu izvođačkih umetnosti. Zagreb/Beograd.

Lukač, Đerđ. 1990. Teorija romana. Veselin Masleša/Svjetlost. Sarajevo.

Mair, Peter. 2013. Ruling the Void. The Hollowing of Western Democracy. Verso. London/New York.

Molijer. 1935. Škola za žene/Mizantrop. Srpska književna zadruga. Beograd.

Pater, Walter. 2002. Plato and Platonism: A Series of Lectures. Cambridge Scholars Press. Adelaide/London/Washington.

Pirandelo, Luiđi. 2011. Šest lica traži pisca. Paideia/Blic. Beograd.

Platon. 1982. Odbrana Sokratova/ Kriton/Fedon. Bigz. Beograd.

Platon. 2005. Država. Dereta. Beograd.

Polanji, Karl. 2003. Velika transformacija. Politička i ekonomska ishodišta našeg vreme$n a$. Filip Višnjić. Beograd.

Popper, Karl. 2003. Otvoreno društvo i njegovi neprijatelji, sv. I: "Platonova čarolija". Kruzak. Zagreb.

Puchner, Martin. 2010. The Drama of Ideas. Platonic Provocations in Theater and Philosophy. Oxford University Press. Oxford.

Rochefoucauld, François. 1935. Maximes. Oeuvres complètes. Gallimard. Paris.

Schmitt, Carl. 1991. Theodor Däublers “Nordlicht”: Drei Studien über die Elemente, den Geist und die Aktualität des Werkes. Duncker \& Humblot. München.

Schmitt, Carl. 2015. Die Diktatur. Von den Anfängen des modernen Souveränitätsgedankens bis zum proletarischen Klassenkampf. Duncker \& Humblot. München.

Shakespeare, William. 1994. A midsummer night's dream. Penguin Books. London.

Sofokle. 1994. Kralj Edip, u: Grčke tragedije II. Srpska književna zadruga. Beograd. 
Šmit, Karl. 2001. Pojam političkog, u: Slobodan Samardžić (ur.): Norma i odluka. Karl Šmit i njegovi kritičari. Filip Višnjić. Beograd.

Šmit, Karl. 2003. Tri vrste pravnonaučnog mišljenja. Dosije. Beograd.

Štraus, Leo. 2001. Napomene uz pojam političkog Karla Šmita, u: Slobodan Samardžić (ur.): Norma i odluka. Karl Šmit i njegovi kritičari. Filip Višnjić. Beograd.

Volin, Šeldon. 2007. Politika i vizija. Filip Višnjić. Beograd.

Wolin, S. Sheldon. 2008. Democracy Incorporated. Managed Democracy and the Specter of Inverted Totalitarianism. Princeton University Press. Princeton/Oxford.

\author{
Bojan Kovačević \\ POLITICS AND THEATER AS GUARDIANS \\ OF A COMMON WORLD
}

\begin{abstract}
Summary
In this paper the author claims that the history of European drama and theater contains an original answer to the classical political question of relation between an order and change. The theater's fundamental goal is preservation of a common world in the absence of which the theater itself becomes meaningless. Confronting us at first with the abyss of searching for the meaning of life, the great dramatists than help us return to the normality by providing us with an answer whispered in their ear by the spiritual, historic and political circumstances of their age. Those among them aiming to preserve the existing order, such as Aeschylus, Molière and Racine, artistically revealed to the audiences the order's grounding idea. For others, such as Goethe and Schiller, whose artistic genius recognized in the history signs of a development towards a republic of autonomous citizens, theater was a place for esthetic education of an elite expected to accelerate the process of coming into being of a new common world. Authors of revolutionary periods, such as Brecht and Pirandello, used theater to inspire radical change of all existing social and political institutions. Finally, to the authors such as Euripides, Ibsen, Chekhov and Strindberg, theater made it possible to cry out for an old common world that no longer has a grounding idea and therefore disappears.
\end{abstract}

Keywords: Political, Theatre, Drama, Common World, Order

Bojan Kovačević je izvanredni profesor na Fakultetu političkih nauka Univerziteta u Beogradu.

Kontakt: Bojan Kovačević, Fakultet političkih nauka, Jove Ilića 165, 11000 Beograd. E-mail: bojan.kovacevic@fpn.bg.ac.rs 